\title{
Bone alkaline phosphatase and osteocalcin expression of rat's Gingival mesenchymal stem cells cultured in platelet-rich fibrin for bone remodeling (in vitro study)
}

\author{
Alexander Patera Nugraha ${ }^{1,2,3}$, Ida Bagus Narmada ${ }^{1}$, Diah Savitri Ernawati ${ }^{4}$, \\ Aristika Dinaryanti ${ }^{3}$, Eryk Hendrianto ${ }^{3}$, Wibi Riawan ${ }^{5}$, Fedik Abdul Rantam ${ }^{3,6}$
}

Correspondence: Dr. Fedik Abdul Rantam

Email: fedik-a-r@fkh.unair.ac.id

\begin{abstract}
'Department of Orthodontic, Faculty of Dental Medicine, Universitas Airlangga, Surabaya, Indonesia, ${ }^{2}$ Doctoral Student of Medical Science, Faculty of Medicine, Universitas Airlangga, Surabaya, Indonesia, ${ }^{3}$ Stem Cell Research and Development Center, Universitas Airlangga, Surabaya, Indonesia, ${ }^{4}$ Department of Oral Medicine Faculty of Dental Medicine, Universitas Airlangga, Surabaya, Indonesia, ${ }^{5}$ Department of Biochemistry and Molecular, Biochemistry Biomolecular Laboratory, Faculty of Medicine, Universitas Brawijaya, Surabaya, Indonesia, ${ }^{6}$ Department of Microbiology, Virology and Immunology Laboratory, Faculty of Veterinary Medicine, Universitas Airlangga, Surabaya, Indonesia
\end{abstract}

\section{ABSTRACT}

Objective: The aim of this study was to analyze the osteogenic differentiation of rat GMSCs cultured in PRF for bone remodeling. Materials and Methods: GMSCs were isolated from the lower gingival tissue of four healthy, 250 g, 1-month old, male rats (Rattus norvegicus) cut into small fragments, cultured for 2 weeks, and subsequently passaged every 4-5 days. GMSCs isolated in passage 3 were characterized by CD34, CD45, CD44, CD73, CD90, and CD105 using fluorescein isothiocyanate immunocytochemistry (ICC) examination. GMSCs in passage 3-5 cultured in five M24 plates $(N=108 ; n=6 /$ group) for 7, 14, and 21 days with three different mediums as follows: Control (-) group: $\alpha$-Modified Eagle Medium; Control (+) group: High-dose glucose Dulbecco's Modified Eagle's Medium (DMEM-HG) + osteogenic medium; and treatment group: DMEM-HG + osteogenic medium + PRF. GMSCs were osteogenic differentiation cultured in vitro in three different mediums by bone alkaline phosphatase (BALP) and osteocalcin (OSC) marker using ICC monoclonal antibody. Statistical Analysis Used: The one-way analysis of variance was performed $(P<0.05)$ based on Shapiro-Wilk and Levene's tests $(P>0.05)$. Results: GMSCs were shown to present + CD44, + CD73, + CD90, + CD105 and - CD34, - and CD45 expression as MSCs markers. The treatment group showed the highest BALP expression (16.00 \pm 1.732$)$ on day 7 , while OSC expression (13.67 \pm 2.309$)$ on day 21 showed

\begin{tabular}{|l|l|}
\hline \multicolumn{2}{|c|}{ Access this article online } \\
\hline Quick Response Code: \\
\hline
\end{tabular}

This is an open access journal, and articles are distributed under the terms of the Creative Commons Attribution-NonCommercial-ShareAlike 4.0 License, which allows others to remix, tweak, and build upon the work non-commercially, as long as appropriate credit is given and the new creations are licensed under the identical terms.

\section{For reprints contact: reprints@medknow.com}

How to cite this article: Nugraha AP, Narmada IB, Ernawati DS, Dinaryanti A, Hendrianto E, Riawan W, et al. Bone alkaline phosphatase and osteocalcin expression of rat's Gingival mesenchymal stem cells cultured in platelet-rich fibrin for bone remodeling (in vitro study). Eur $\mathrm{J}$ Dent 2018;12:566-73.

DOI: 10.4103/ejd.ejd_261_18 
Nugraha, et al.: Bone alkaline phosphatase and osteocalcin expression in gingival mesenchymal stem cells with platelet-rich fibrin

the statistically significant difference between groups $(P<0.05)$. Conclusion: GMSCs cultured in PRF demonstrated potential osteogenic differentiation ability capable of accelerating in vitro bone remodeling by enhancing BALP and OSC expression.

Key words: Bone alkaline phosphatase, gingival mesenchymal stem cells, osteocalcin, osteogenic differentiation, platelet-rich fibrin

\section{INTRODUCTION}

Bone defect regeneration remains problematic in the fields of medicine and dentistry. Various efforts have been made to accelerate bone regeneration, one of them being Mesenchymal Stem Cells (MSCs). therapy which offers a promising solution for deep approach bone regeneration. ${ }^{[1-3]}$ The MSCs possess multipotent capabilities, paracrine and autocrine, and migration capacity to the tissue directly initiate healing and regeneration. ${ }^{[4-6]}$

The orofacial region is a unique and rich source of MSCs. Those from tooth tissue and the oral cavity represent an interesting, emerging development because the progenitor cell isolation from oral tissues can be completed through minimally invasive procedures resulting in reduced infection. Oral cavity MSCs utilization has rarely been studied and applied, despite its potential in tissue regeneration. Further investigation is, therefore, required. ${ }^{[7-9]}$

Gingival Mesenchymal Stem Cells (GMSCs) can be obtained from hyperplastic gingiva. GMSCs have similar phenotypic to bone marrow stem cells (BMSCs), demonstrate self-renewal capabilities, and specifically induce bone matrix formation in lamellar structures by recruiting host cells. The osteogenic ability of GMSCs needs to be explored for further application and therapy. $[2,9,7,10]$

To achieve optimal differentiation and proliferation, GMSCs require growth factors (GFs). Platelet-rich fibrin (PRF) is an easily manufactured containing abundant GFs. PRF consisting of abundant platelet-derived GF- $\beta$, transforming GF- $\beta 1$ (TGF- $\beta 1$ ), vascular endothelial GF (VEGF), and insulin growth factor (IGF-I)..$^{[11-14]}$

PRF fibrin matrix possesses flexible, elastic, and strong properties. It is composed of thrombin concentrations with equilateral bonds forming fine and flexible fibrin networks that support cytokines and cell migration. PRF provides an effective scaffold to facilitate osteogenic differentiation of GMSCs. ${ }^{[15,16]}$ The aim of this study is to analyze the ability of osteogenic differentiation of a combination of GMSCs and PRF for in vitro bone remodeling by bone alkaline phosphatase (BALP) and OSC expression.

\section{MATERIALS AND METHODS}

\section{Ethical clearance}

Thisstudy received ethical clearance approval for animal subjects (number: 289/HRECC.FODM/XII/2017) from the Ethics Research Committee of the Faculty of Dental Medicine, Universitas Airlangga Surabaya, East Java, Indonesia. The research was conducted at an experimental laboratory within the Stem Cell and Tissue Engineering Development Centre, Universitas Airlangga, Surabaya, East Java, Indonesia.

\section{Research design}

The research was fully experimental with a posttest-only control group design. Sample groups were selected using simple random number sampling. The subjects consisted of male Wistar rats (Rattus novegicus; $n=4$ ), obtained from the Stem Cell Animal Laboratory, Universitas Airlangga, which were adapted to the environment over 7 days.

GMSCs were isolated from the lower gingival tissue of 41-month old, healthy, male rats with a mean weight of $250 \mathrm{~g}$ using a gingivectomy. The research subjects were subsequently euthanized with $60 \mathrm{mg} /$ body weight doses of ketamine and xylazine. Their suffering had been reduced when removing the GMSCs due to the administrating of anesthesia (intramuscular injection at 0.05-0.1 ml/10 g body weight rodent anesthesia: ketamine, xylazine, acepromazine, and sterile isotonic saline; Sigma Aldrich, USA).

GMSCs were passaged every 4-5 days in accordance with Rantam et al.'s MSCs culture method. GMSCs in passage 3-5 were cultured in five M24 plates (Sigma-Aldrich) $(N=108 ; n=6$ /group) until day 7,14 , and 21 in three different culture media (control negative group, control positive group, and treatment group). Sample size ( $n=4$ for GMSCs isolation; $n=36$ for PRF isolation) was based on Lemeshow's formula to determine minimum sample size. 


\section{Gingival mesenchymal stem cells isolation and culture procedure}

GMSCs isolation and culture were performed based on Rantam et al.'s method. ${ }^{[17]}$ The subjects were euthanized by an intraperitoneal injection of 50-60 mg/BW ketamine before a gingivectomy was performed. The subjects' gingiva was cut into small fragments and cultured for 2 weeks. The culture was passaged every $4-5$ days. Gingival tissue was attached to a 15-ml heparin tube (Sigma Aldrich ${ }^{\circledR}$, USA) previously filled with 3-ml $\alpha$-MEM. Each gingival tissue was transferred to a $15-\mathrm{ml}$ sterile Durham bottle and diluted with $1 \times 8 \mathrm{ml}$ sterile phosphate buffer saline (PBS) (Sigma Aldrich ${ }^{\circledR}$, USA). Each tube was rinsed twice with $5 \mathrm{ml} \times$ PBS combined with an aspirate solution. The gingival tissue was placed in a Ficoll (Sigma Aldrich ${ }^{\circledR}$, USA) temperature chamber in a separate 15-ml tube. Furthermore, each aspirate was coated with Ficoll before being centrifuged (Sorvall ${ }^{\mathrm{TM}}$ Micro-Ultracentrifuge, ThermoFisher, USA) at $1600 \mathrm{rpm}$ for $15 \mathrm{~min}$ at room temperature. Each sample was diluted with $1 \times 15 \mathrm{ml}$ PBS, the tube being turned 3-5 times as a means of achieving an even mix. Centrifugation was undertaken for $10 \mathrm{~min}$ at $1600 \mathrm{rpm}$ before the supernatant, and cells suspended in 6-ml CCM were removed and heated. Between 5 and $10 \mathrm{~cm}$ of the cells were removed from the tube and placed on the plate. They were incubated at $37^{\circ} \mathrm{C}$ at $5 \% \mathrm{CO}_{2}$ moisture and allowed to cell attach for 18-24 h.

Approximately $24 \mathrm{~h}$ later, the mediums and cells not attached were disposed of. $5 \mathrm{ml} \mathrm{1x}$ PBS was then added before being heated in the culture, agitated thoroughly, and used to cover the surface area. It was then disposed of with $1 \times$ PBS before the washing process being repeated twice. Ten minutes later, $10 \mathrm{ml}$ of fresh CCM was added to the dish before it was returned to the incubator. The cells were incubated at $37^{\circ} \mathrm{C}$ and $5 \%-10 \% \mathrm{CO}_{2}$ moisture with the culture being observed daily through an inverted microscope. The medium was removed and the cells rinsed with $5 \mathrm{ml}$ or $10 \mathrm{ml}$ of $1 \times$ PBS before heating every 3 days. The PBS was subsequently discarded and the dish filled with $10 \mathrm{ml}$ of fresh CCM. This process was continued until the concentration of confluent cells reached $80 \%-90 \%$. If the cell developed in the cell plant, the latter had to be placed in the incubator at $5 \% \mathrm{CO}_{2}$ moisture and $37^{\circ} \mathrm{C}$ for $48 \mathrm{~h}$ before use.

Gingival mesenchymal stem cell characterization using immunofluorescence

GMSCs characterization using immunofluorescence was conducted based on the findings contained in the study authored by Jin et al. ${ }^{[18]}$ Trypsin was added and centrifuged at $1600 \mathrm{rpm}$ for $5 \mathrm{~min}$. The pellets were added to $1 \mathrm{ml}$ of $\alpha$-Modified Eagle Medium ( $\alpha$-MEM) growth medium (Sigma Aldrich ${ }^{\circledR}$, USA). GMSCs were cultured in a chamber slide (BD Biosciences, USA) suspended and grown in a $20-\mu l$ special glass. The glass object was placed in a box containing wet paper, incubated at $37^{\circ} \mathrm{C}$ for $1 \mathrm{~h}$ before, and $10 \%$ paraformaldehyde (Sigma-Aldrich Co.) was used to fix the cells. The result was then permeabilized in PBS and 1\% Triton X100 for 3 min. GMSCs were stained with anti-CD34, anti-CD44, anti-CD45, anti-CD73, anti-CD90, and anti CD105 monoclonal antibodies (Sigma Aldrich ${ }^{\circledR}$, USA) being added to each sample and then incubated at $37^{\circ} \mathrm{C}$ for $45 \mathrm{~min}$. The PBS washing and drying process was repeated. At the next stage, an immunofluorescence examination of the glass object was conducted with $50 \%$ glycerin being added and the results observed through a fluorescent microscope (Automated Fluorescence Microscope, BX63, Olympus ${ }^{\circledR}$, USA).

\section{platelet-rich fibrin isolation}

A different population of subjects was used for PRF isolation $(n=36 ; 36$ months old; and mean weight $=250 \mathrm{~g}$ ). These male Wistar rats were maintained as described above. Blood was aspirated through the left ventricle of each subject's heart after anesthesia had been administered by injection using a $60 \mathrm{mg} /$ body weight dose of ketamine and a $3 \mathrm{mg} /$ body weight dose of xylazine (Sigma Aldrich). A volume of $1.5 \mathrm{ml}$ of blood was aspirated using a $3 \mathrm{ml}$ disposable syringe and then inserted into a vacutainer tube without an anticoagulant before being centrifuged at $3000 \mathrm{rpm} / \mathrm{min}$ for $10 \mathrm{~min}$ (Kubota, Tokyo, Japan). When the tube was removed from the centrifuge, three distinct layers were evident, each of which was divided into three sections: the lower consisting of red blood cells, the middle containing PRF, and the upper formed of acellular plasma. The PRF was then isolated after which the PRF was cut into small pieces using sterile scissors and inserted into each culture plate of the treatment group. ${ }^{[16,19,20]}$

Osteogenic differentiation of combination platelet-rich fibrin and gingival mesenchymal stem cells

The analysis was conducted on three groups, consisting of two control groups and one experimental group. The GMSCs treatment group cultured in PRF was placed in the culture plate containing $2 \mathrm{mM}$ L-glutamine, $100 \mu \mathrm{g} / \mathrm{ml}$ sodium pyruvate, $0.2 \mathrm{mM}$ ascorbic acid-2 phosphate, dexamethasone $10-7 \mathrm{M}$ as 
osteogenic medium (GeneTex, AS), $10 \mathrm{ng} / \mathrm{ml} \mathrm{TGF- \beta 3,}$ and High-Dose glucose Dulbecco's Modified Eagle Medium (DMEM-HG). The positive control group featured GMSCs placed on culture plate containing $2 \mathrm{mM}$ L-glutamine, $100 \mu \mathrm{g} / \mathrm{ml}$ sodium pyruvate, $0.2 \mathrm{mM}$ ascorbic acid-2 phosphate, dexamethasone $10-7 \mathrm{M}$ as osteogenic medium (GeneTex, AS), $10 \mathrm{ng} / \mathrm{ml}$ TGF- $\beta 3$, and DMEM-HG. The negative control group contained GMSCs with $\alpha$-MEM. Each group cell medium was replaced every 3 days. Osteogenic differentiation of the culture cells was evaluated on days 7,14 , and $21 .{ }^{[16]}$

GMSCs cultured cells were coated with coverslips and after incubation at $37^{\circ} \mathrm{C}$ for $1-2 \mathrm{~h}$ were fixed using 10\% formaldehyde for $15 \mathrm{~min}$. The coverslips were then rinsed four times with PBS and dried for several minutes. The cells were blocked with PBS and 1\% for 15-30 min and washed four times with PBS. Samples were examined by indirect technique using immunocy tochemical staining using a 3.3'-diaminobenzidine staining kit (DAB) (Pierce $^{\mathrm{TM}}$ DAB Substrate Paint Kit 34002, ThermofisherTM, Waltham, Massachusetts, United States), monoclonal antibodies (Santa Cruz Biotechnology ${ }^{\mathrm{TM}}$, BALP sc271431), and osteocalcin (OSC) (anti-OSC sc365797). At that point, the cell was suitable for microscopic analysis..$^{[13,17,21]}$

BALP and OSC expression was monitored using a light microscope (CX22 Binocular, Olympus) at 200× magnification. Every cell expressing BALP or OSC in one field was examined three times by a trio of experts (WR, EH, and FAR) with the mean subsequently being calculated.

\section{Data analysis}

The data obtained was analyzed statistically using the one-way analysis of variance $(P<0.05)$ based on a Shapiro-Wilk normality test and a Levene's variance homogeneity test $(P>0.05)$ with a Statistical Package for the Social Sciences Software 20.0 edition (IBM ${ }^{\mathrm{TM}}$, Illinois, Chicago, USA).

\section{RESULTS}

In the early stages, GMSCs isolates presented small, round cell morphology, spindle-shaped, fibroblast-like, and attached to plate culture when observed with an electron microscope in the first to fifth passages [Figure 1]. GMSCs express positive SPCs markers such as positive CD44, CD73, CD90, and CD105 [Figure 2]. In contrast, GMSCs did not express

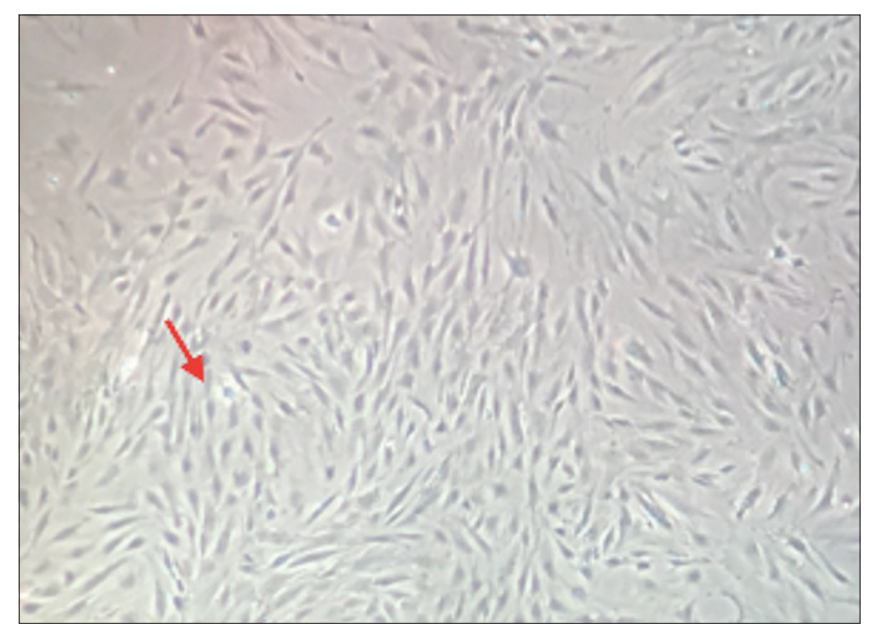

Figure 1: Gingival mesenchymal stem cells morphology showed fibroblast-like cells with spindle-shaped and attached in culture plate (red arrow). Examination by electron microscope (CX22 Binocular, Olympus) $(\times 100)$

hematopoietic stem cells markers that are negative to CD34 and CD45 [Figure 3].

The positive expression of BALP in GMSCs showed brown cells, BALP highly expressed in treatment group day 7 [Figure 4]. The positive expression of OSC in GMSCs showed brown cells, OSC highly expressed in treatment group day 21 [Figure 5].

The data obtained was normal and homogeneous distributed $(P>0.05)$. The highest average BALP expression was in the treatment group on day 7 whereas BALP expression was found to be lowest in the negative control group on day 21. OSC expression had the highest mean value in the day 21 treatment group, while OSC expression was found to be lowest in the negative control group on day 7. There was a statistically significant difference between BALP and OSC expression in each group $(P<0.05)$ [Tables 1 and 2].

\section{DISCUSSION}

The highest BALP expression was found in the treatment group in day 7 in line with the assertion of Kamadjaja et al. that MSCs have osteogenic differentiation capability through the increased expression of BALP detected by alizarin red staining..$^{[13]}$ Kuo et al. supported the view that BALP expression peaked on day 7 and began to decrease on day 14 . GF such as IGF also increases BALP expression significantly because IGF-bind IGF-R1 stimulates osteogenic ability. PRF contained IGF has an important role in progenitor cells proliferation, differentiation, survival, and migration. ${ }^{[22,23]}$ 

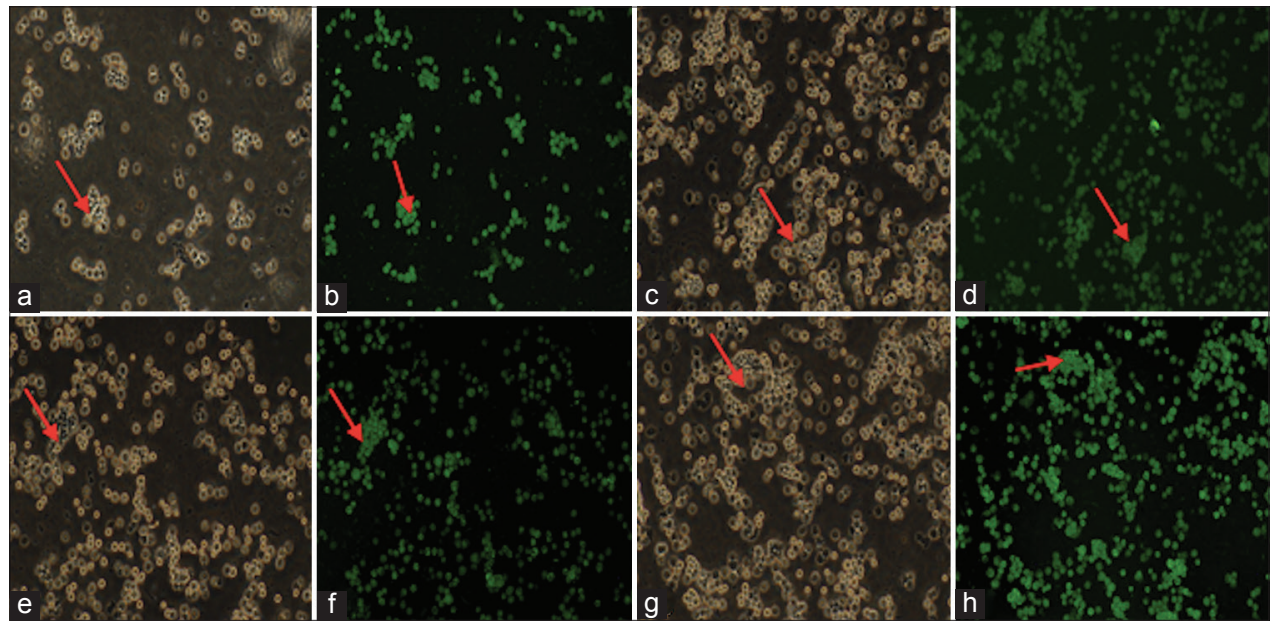

Figure 2: Immunocytochemistry examination based on the immunofluorescence of GMSCs expressed cell surface marker confirmed positive expression (+) (red arrow). (a and b) CD44; (c and d) CD73; (e and f) CD90; (g and h) and CD105 fluorescein isothiocyanate labeled. Examination by electron microscope (Immunofluorescence Microscope, Olympus) $(\times 100)$
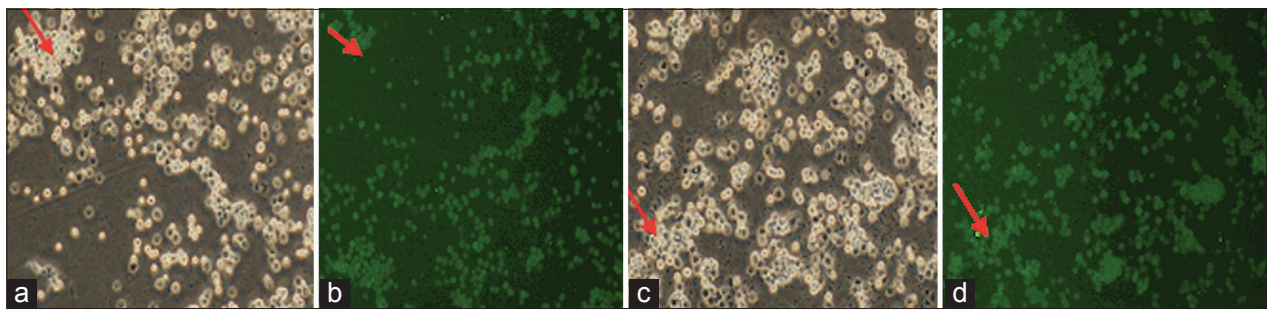

Figure 3: Immunocytochemistry examination using immunofluorescence of gingival mesenchymal stem cells expressed cell surface marker of hematopoietic stem cells showed negative expression (-) (red arrow). (a and b) (-) CD34; (c and d) (-) CD45 fluorescein isothiocyanate- labeled. Examination by electron microscope (Immunofluorescence Microscope, Olympus) $(\times 100)$

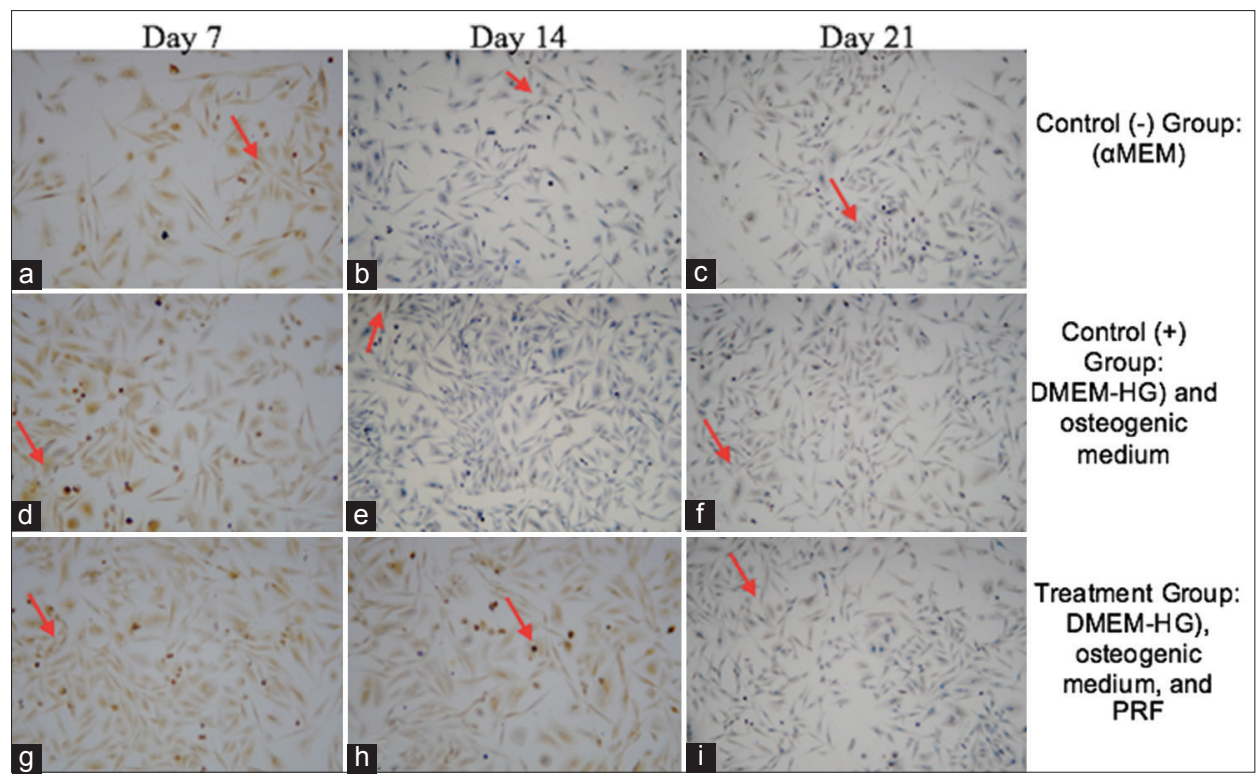

Figure 4: Bone alkaline phosphatase expression in gingival mesenchymal stem cells Wistar rats (Rattus novegicus); (a-c) Alkaline phosphatase expression in negative control group; (d-f) bone alkaline phosphatase expression in positive control group; and (g-i) bone alkaline phosphatase expression in treatment group. Bone alkaline phosphatase expression in gingival mesenchymal stem cells was observed on day 7, 14 , and 21. Positive bone alkaline phosphatase expression marked in brown (red arrow) examination with CX22 Binocular, Olympus (×200)

BALP is a metalloenzyme secreted by several tissues and expressed at the outset of tissue development. BALP can be observed in the cell surface as well as the matrix vesicles. The regulation of BALP expression is vital in the early stages of bone tissue development and formation. BALP expression is an 
Nugraha, et al.: Bone alkaline phosphatase and osteocalcin expression in gingival mesenchymal stem cells with platelet-rich fibrin

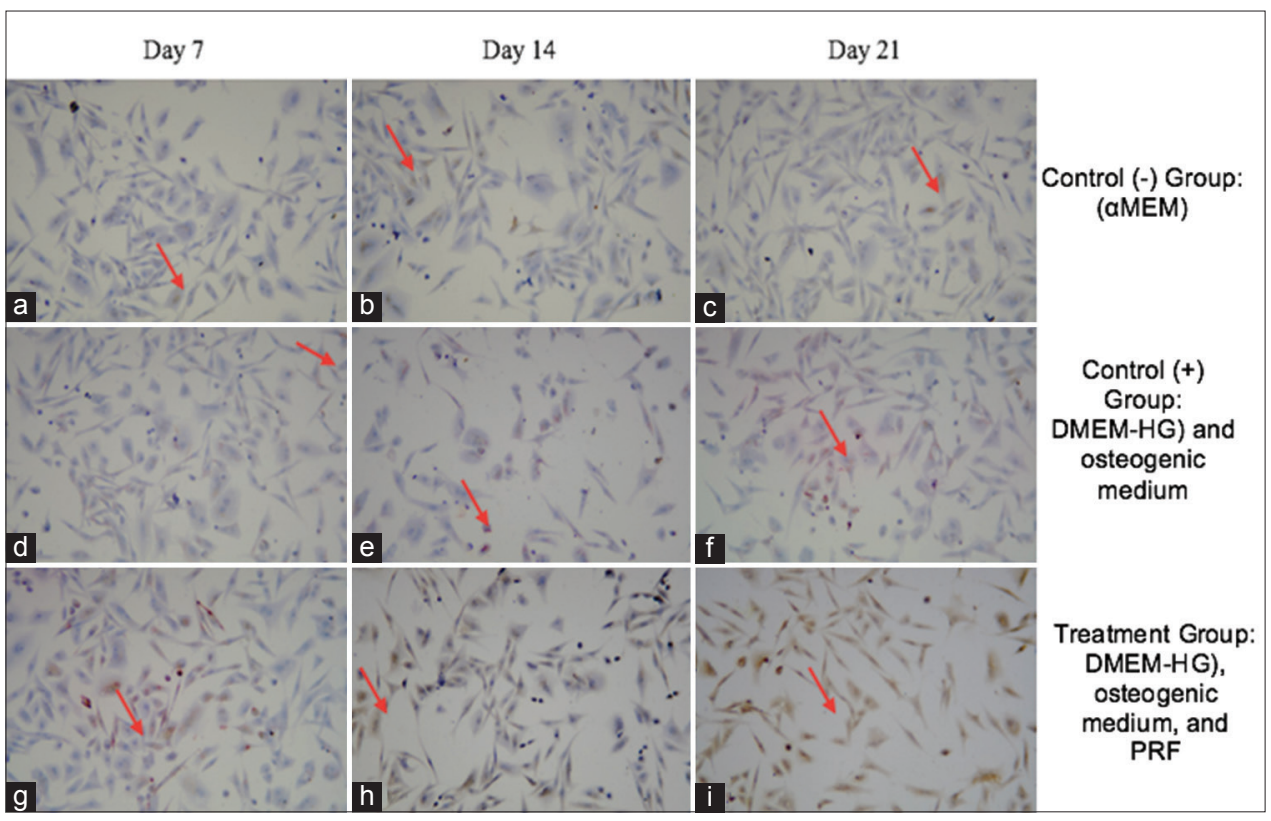

Figure 5: Osteocalcin expression in gingival mesenchymal stem cells Wistar rats (Rattus novegicus); (a-c) Osteocalcin expression in negative control group; (d-f) Osteocalcin expression in positive control group; and (g-i) osteocalcin expression in the treatment group. Osteocalcin expression in gingival mesenchymal stem cells was observed on day 7, 14, and 21. Positive osteocalcin expression marked with brown (red arrow) examination with CX22 Binocular, Olympus (×200)

\begin{tabular}{|c|c|c|c|c|}
\hline \multirow[t]{2}{*}{ Time } & \multicolumn{3}{|c|}{ BALP expression } & \multirow[t]{2}{*}{ One-way ANOVA $(P)$} \\
\hline & Negative control group & Positive control group & Treatment group & \\
\hline Day 7 & $11.33 \pm 2.517$ & $11.33 \pm 1.528$ & $16.00 \pm 1.732$ & $0.00^{*}$ \\
\hline Day 14 & $7.67 \pm 2.082$ & $9.67 \pm 1.155$ & $10.67 \pm 1.528$ & $0.00^{*}$ \\
\hline Day 21 & $4 \pm 1.000$ & $9.67 \pm 1.155$ & $9.67 \pm 1.155$ & $0.00^{*}$ \\
\hline
\end{tabular}

\begin{tabular}{|c|c|c|c|c|}
\hline \multirow[t]{2}{*}{ Time } & \multicolumn{3}{|c|}{ OSC expression } & \multirow[t]{2}{*}{ One-way ANOVA $(P)$} \\
\hline & Negative control group & Positive control group & Treatment group & \\
\hline Day 7 & $3.33 \pm 1.528$ & $8.33 \pm 1.155$ & $10 \pm 1.000$ & $0.00^{*}$ \\
\hline Day 14 & $7.00 \pm 1.000$ & $9.33 \pm 0.577$ & $12.33 \pm 3.055$ & $0.00^{*}$ \\
\hline Day 21 & $7.00 \pm 2.646$ & $11.00 \pm 1.000$ & $13.67 \pm 2.309$ & $0.00^{*}$ \\
\hline
\end{tabular}

early marker of osteogenic cell differentiation from day 5 to 14 and decreases while OSC increases. The combination of PRF and GMSCs enhances BALP expression because PRF contains many GFs. TGF- $\beta$ in PRF stimulates progenitor cell proliferation and differentiation with osteoblastic mitogenesis. ${ }^{[19,24,25]}$ Yang et al. argued that PRF significantly increased BALP expression and mRNA levels of osteogenic marker that reduces adipogenic capability. ${ }^{[26]}$ PRF stimulates $\beta$-catenin and inhibits Dickkopf-related protein 1 (DKK1). DKK is an inhibitory factor of GMSCs differentiation. DKK1 and $\beta$-catenin were the fundamental principles of signaling pathways of osteogenesis and chondrogenesis differentiation control and regulation. BALP expression increased because of signaling bone morphogenic protein, runt-related transcription factor 2 or core-binding factor subunit alpha-1, osterix system, and Wnt cascade interacting with each other. JAK/STAT3 signaling also contributes to stimulate BALP expression. STAT3 plays an important role in the pluripotent ability of GMSCs. Cell nucleus translocation activates STAT3 that regulates pluripotent genes of progenitor cells. ${ }^{[27]}$ 
The peak of increased OSC expression occurred on day 21 in the treatment group in accordance with Duan et al. s' identifying of an increase OSC expression on day 21 as analyzed by reverse transcription polymerase chain reaction. ${ }^{[28]}$ PRF can promote the regeneration of hard and soft tissue, thus accelerating and enhancing wound healing quality. PRF contains TGF- $\beta 1$ that plays an important role in stimulating fibrosis, PDGF contributes to progenitor cell migration and survival, IGF prevents cells from premature apoptosis, and VEGF stimulates vasculogenesis and angiogenesis, while EGF is active during cell proliferation and differentiation. ${ }^{[19,25]}$ PRF can increase the expression of protein kinase and osteoprotegerin in osteoblasts that can stimulate osteoblast proliferation indicating the potential to form new bone formation. PRF is also capable of inducing MSCs to differentiate into in vitro osteoblasts such as BMSCs. ${ }^{[28-33]}$

OSC is a secreted protein dependent by Vitamin $\mathrm{K}$ which is a macromolecule that implies $1 \%-2 \%$ bone mineralization consisting of bone matrix. OSC has an important role to maintain calcium level homeostasis. ${ }^{[34]}$ OSC expression is a bone-specific protein synthesized by osteoblasts that can be used as a specific end-stage osteogenic differentiation marker. Osteogenic-differentiated cells should produce and secrete OSC before the mineralization process. OSC expression genes can be detected on day 14 during culture and strongly expressed during the day 14-28 period. ${ }^{[35]}$

OSC levels and expression also can be used as predictive markers of bone fracture and metabolism. In early 1990, OSC serum was identified as a marker of bone formation and remodeling. OSC is also associated with testosterone and bone maturation in males. Previous studies conducted on the child population have confirmed OSC serum to be a sensitive biochemical marker of skeletal development and growth. ${ }^{[35,36]}$

\section{CONCLUSION}

GMSCs cultured in PRF possess potential osteogenic differentiation ability capable of accelerating bone remodeling in vitro by increased expression of BALP and OSC.

\section{Acknowledgments}

The authors would like to thank the Postgraduate School, Faculty of Dental Medicine, Faculty of Medicine, Stem Cell Research and Development
Centre, Universitas Airlangga, for its support of the research reported here.

\section{Financial support and sponsorship}

The research was funded by the Progam Menuju Doktor Sarjana Unggul Batch III of the Ministry of Research, Technology and Higher Education of the Republic of Indonesia (Kemenristekdikti RI) (letter of appointment agreement number, 1035/D3/PG/2017; grant n3ber 2146/D3/PG/2017).

\section{Conflicts of interest}

There are no conflicts of interest.

\section{REFERENCES}

1. Barzilay R, Melamed E, Offen D. Introducing transcription factors to multipotent mesenchymal stem cells: Making transdifferentiation possible. Stem Cells 2009;27:2509-15.

2. Egusa H, Sonoyama W, Nishimura M, Atsuta I, Akiyama K. Stem cells in dentistry - part I: Stem cell sources. J Prosthodont Res 2012;56:151-65.

3. Ponnaiyan D, Jegadeesan V. Comparison of phenotype and differentiation marker gene expression profiles in human dental pulp and bone marrow mesenchymal stem cells. Eur J Dent 2014;8:307-13.

4. Augello A, Kurth TB, de Bari C. Mesenchymal stem cells: A perspective from in vitro cultures to in vivo migration and niches. Eur Cells Mater 2010;20:121-33.

5. Law S, Chaudhuri S. Mesenchymal stem cell and regenerative medicine: Regeneration versus immunomodulatory challenges. Am J Stem Cells 2013;2:22-38.

6. Gao F, Chiu SM, Motan DA, Zhang Z, Chen L, Ji HL, et al. Mesenchymal stem cells and immunomodulation: Current status and future prospects. Cell Death Dis 2016;7:e2062.

7. Miran S, Mitsiadis TA, Pagella P. Innovative dental stem cell-based research approaches: The future of dentistry. Stem Cells Int 2016;2016:7231038.

8. Diomede F, Rajan TS, Gatta V, D'Aurora M, Merciaro I, Marchisio M, et al. Stemness maintenance properties in human oral stem cells after long-term passage. Stem Cells Int 2017;2017:5651287.

9. Egusa H, Sonoyama W, Nishimura M, Atsuta I, Akiyama K. Stem cells in dentistry - Part II: Clinical applications. J Prosthodont Res 2012;20:229-48.

10. Niibe K, Suehiro F, Oshima M, Nishimura M, Kuboki T, Egusa H, et al. Challenges for stem cell-based "regenerative prosthodontics". J Prosthodont Res 2017;61:3-5.

11. Baek HS, Lee HS, Kim BJ, Chung IK, Kim CH, Jin SM, et al. Effect of platelet-rich fibrin on repair of defect in the articular disc in rabbit temporomandibular joint by platelet-rich fibrin. Tissue Eng Regen Med 2011;8:530-5.

12. Kazemi D, Fakhrjou A, Dizaji VM, Alishahi MK. Effect of autologous platelet rich fibrin on the healing of experimental articular cartilage defects of the knee in an animal model. Biomed Res Int 2014;2014:486436.

13. Kamadjaja MJ, Salim S, Rantam FA. Osteogenic potential differentiation of human amnion mesenchymal stem cell with chitosan- carbonate apatite. Bali Med J 2016;5:71-7.

14. Zeidán-Chuliá F, Noda M. "Opening" the mesenchymal stem cell tool box. Eur J Dent 2009;3:240-9.

15. Granéli C, Thorfve A, Ruetschi U, Brisby H, Thomsen P, Lindahl A, et al. Novel markers of osteogenic and adipogenic differentiation of human bone marrow stromal cells identified using a quantitative proteomics approach. Stem Cell Res 2014;12:153-65.

16. Nugraha AP, Narmada IB, Ernawati DS, Dinaryanti A, Hendrianto E, Ihsan IS, et al. Osteogenic potential of gingival stromal progenitor cells cultured in platelet rich fibrin is predicted by core-binding factor subunit- $\alpha 1 /$ Sox 9 expression ratio (in vitro) [version 1 ; referees: 1 approved, 2 approved with reservations]. F1000Research 2018;7:1134. 
17. Rantam FA, Nugraha AP, Narmada IB, Ernawati DS, Widodo ADW, Lestari $\mathrm{P}$, et al. Gingival mesenchymal stem cells from wistar rat's gingiva (Rattus Novergicus) - Isolation and characterization (In Vitro Study). J Int Med Res 2018;11:694-9.

18. Jin SH, Lee JE, Yun JH, Kim I, Ko Y, Park JB, et al. Isolation and characterization of human mesenchymal stem cells from gingival connective tissue. J Periodontal Res 2015;50:461-7.

19. Borie E, Oliví DG, Orsi IA, Garlet K, Weber B, Beltrán V, et al. Platelet-rich fibrin application in dentistry: A literature review. Int J Clin Exp Med 2015;8:7922-9.

20. Rahmawati D, Roestamadji RI, Yuliati A, Bramantoro T. Osteogenic ability of combined hematopoetic stem cell, hydroxyapatite graft and platelet rich fibrin on rats (Rattus novergicus). J Krishna Instit Med Sci Univ 2017;6:88-95.

21. Ekizer A, Yalvac ME, Uysal T, Sonmez MF, Sahin F. Bone marrow mesenchymal stem cells enhance bone formation in orthodontically expanded maxillae in rats. Angle Orthod 2015;85:394-9.

22. Kuo YC, Au HK, Hsu JL, Wang HF, Lee CJ, Peng SW, et al. IGF-1R promotes symmetric self-renewal and migration of alkaline phosphatase+germ stem cells through HIF-2 $\alpha$-OCT4/CXCR4 loop under hypoxia. Stem Cell Reports 2018;10:524-37.

23. Kobayashi E, Flückiger L, Fujioka-Kobayashi M, Sawada K, Sculean A, Schaller B, et al. Comparative release of growth factors from PRP, PRF, and advanced-PRF. Clin Oral Investig 2016;20:2353-60.

24. Li Q, Reed DA, Min L, Gopinathan G, Li S, Dangaria SJ, et al. Lyophilized platelet-rich fibrin (PRF) promotes craniofacial bone regeneration through runx2. Int J Mol Sci 2014;15:8509-25.

25. Cortese A, Pantaleo G, Borri A, Caggiano M, Amato M. Platelet-rich fibrin (PRF) in implant dentistry in combination with new bone regenerative technique in elderly patients. Int J Surg Case Rep 2016;28:52-6.

26. Yang S, En L, Yanwei G, Mingguo W. Platelet-rich fibrin promotes osteogenic differentiation of bone marrow mesenchymal stem cells through canonical $\mathrm{Wnt} / \beta$-catenin signaling pathway. Int J Oral Maxillofac Surg 2015;44:e310.

27. Loebel C, Czekanska EM, Bruderer M, Salzmann G, Alini M, Stoddart MJ, et al. In vitro osteogenic potential of human mesenchymal stem cells is predicted by runx2/Sox9 ratio. Tissue Eng Part A 2015;21:115-23

28. Duan $X$, Lin Z, Lin X, Wang Z, Wu Y, Ji M, et al. Study of platelet-rich fibrin combined with rat periodontal ligament stem cells in periodontal tissue regeneration. J Cell Mol Med 2018;22:1047-55.

29. Dohan Ehrenfest DM, Diss A, Odin G, Doglioli P, Hippolyte MP, Charrier JB, et al. In vitro effects of choukroun's PRF (platelet-rich fibrin) on human gingival fibroblasts, dermal prekeratinocytes, preadipocytes, and maxillofacial osteoblasts in primary cultures. Oral Surg Oral Med Oral Pathol Oral Radiol Endod 2009;108:341-52.

30. He L, Lin Y, Hu X, Zhang Y, Wu H. A comparative study of platelet-rich fibrin (PRF) and platelet-rich plasma (PRP) on the effect of proliferation and differentiation of rat osteoblasts in vitro. Oral Surg Oral Med Oral Pathol Oral Radiol Endod 2009;108:707-13.

31. Huang FM, Yang SF, Zhao JH, Chang YC. Platelet-rich fibrin increases proliferation and differentiation of human dental pulp cells. J Endod 2010;36:1628-32.

32. Dohan Ehrenfest DM, Doglioli P, de Peppo GM, Del Corso M, Charrier JB. Choukroun's platelet-rich fibrin (PRF) stimulates in vitro proliferation and differentiation of human oral bone mesenchymal stem cell in a dose-dependent way. Arch Oral Biol 2010;55:185-94.

33. Chang IC, Tsai CH, Chang YC. Platelet-rich fibrin modulates the expression of extracellular signal-regulated protein kinase and osteoprotegerin in human osteoblasts. J Biomed Mater Res A 2010;95:327-32.

34. Paldanius PM. The Role of Osteocalcin in Human Bone Metabolism and Glucose Homeostasis. Academic Disertation; 2017. Available from: https://www.helda.helsinki.fi/bitstream/handle/10138/173087/ THEROLEO.pdf?sequence=1. [Last accessed on 2018 Jun 01].

35. Nakamura A, Dohi Y, Akahane M, Ohgushi H, Nakajima H, Funaoka $\mathrm{H}$, et al. Osteocalcin secretion as an early marker of in vitro osteogenic differentiation of rat mesenchymal stem cells. Tissue Eng Part C Methods 2009;15:169-80.

36. Li Q, Pan S, Dangaria SJ, Gopinathan G, Kolokythas A, Chu S, et al Platelet-rich fibrin promotes periodontal regeneration and enhances alveolar bone augmentation. Biomed Res Int 2013;2013:638043. 